\title{
Influence of the Powder Pack Boriding Mixture on the FeB and $\mathrm{Fe}_{2} \mathrm{~B}$ Layers
}

M Ortiz-Domínguez ${ }^{1 *}$, G Ares de Parga ${ }^{2}$, A Arenas-Flores ${ }^{1}$, I Morgado-Gonzalez $^{1}$, OA Gómez-Vargas ${ }^{3}$, $\mathrm{J}_{\text {Zuno-Silva }}{ }^{1}$ and A Cruz-Avilés ${ }^{1}$

1. Department of Mechanical Engineering, Universidad Autónoma del Estado de Hidalgo-Campus Sahagún, Hidalgo, México.

2. Department of Physics, Instituto Politécnico Nacional-ESFM, Cd. México, México.

${ }^{3 .}$ Research and Postgraduate Division, Instituto Tecnológico de Tlalnepantla, EdoMéx, México.

* Corresponding author: martin_ortiz@uaeh.edu.mx.edu

Production of hard coatings has been carried out using various materials and material combinations until today. As hard coating material, generally, nitrides, carbides, borides, and oxides of transition metals are used. Hard coatings are thin films which are deposited on tool substrates in order to improve their desired properties such as hardness, friction, wear resistance, and corrosion resistance, while not changing properties of the bulk material. From a functional point of view the most important coating properties are hot hardness, good adhesion to the substrate, and chemical stability. The coating performance can be further improved by optimum coating thickness, fine microstructure, and compressive residual stresses. Boriding coatings technique is gaining popularity in recent years due to their potential for enhancing the wear and corrosion properties and hence, widening their industrial applications. Under a given condition, wear behaviour can depend on the combination of surface engineering methods that are applied to the contacting surfaces [1-3]. In the present study proposes a powder mixture with a controlled boriding potential to avoid generating the FeB coating at the surface of the AISI M2 borided steel by the powder-pack method. The powder-pack boriding process was conducted on cubic commercial samples of AISI M2 with a thickness of $5 \mathrm{~mm}$. The samples were embedded in a closed, cylindrical case at $1273 \mathrm{~K}$ for times up to $8 \mathrm{~h}$ using five different $\mathrm{B}_{4} \mathrm{C}$-base powders (see Figure 1). The powder compositions are reported in Table 1. The powder-pack boriding process was carried out in a conventional furnace under a pure argon atmosphere. One the boriding treatment was finished the container was removed from the furnace and slowly cooled to room temperature. The hard samples were cross-sectioned and resin-embedded for traditional metallographic preparation; were grinded with $\mathrm{SiC}$ abrasive paper up to grit 2500. Afterwards, the samples were polished using a diamond suspension with particle size of $6 \mu \mathrm{m}$, finishing with particle size of $3 \mu \mathrm{m}$, then the polished samples were etched in a $2 \%$ nital solution to observe the boride layer depths formed on the surface of AISI M2. The boride layer depths and morphology were analysed by Scanning Electron Microscopy (SEM), Energy Dispersive Spectroscopy (EDS) and X-ray diffraction (XRD) patterns were collected on the surface of the borided AISI M2. Figures 2 shows the cross-sections of boride layers formed on the surface of AISI M2 at $1273 \mathrm{~K}$ for $8 \mathrm{~h}$. The formation of a double-phase layer $\left(\mathrm{FeB}+\mathrm{Fe}_{2} \mathrm{~B}\right)$ was revealed with a flat morphology in AISI M2. This particular morphology is attributed to the presence of the alloying elements in the substrate of AISI M2 and can be explained by the existence of activated diffusion pathways in the $\mathrm{Fe}_{2} \mathrm{~B}$ and $\mathrm{FeB}$ crystal lattices. It is known that the alloying elements modify the morphology of $\left(\mathrm{FeB} / \mathrm{Fe}_{2} \mathrm{~B}\right.$ and $\mathrm{Fe}_{2} \mathrm{~B} /$ substrate $)$ interfaces and tend to concentrate at the tips of the boride needles by generating a flat morphology. The results of XRD studies presented in Fig. 3a, 3b, 3c and Fig. 3d show the XRD pattern recorded on the surface of borided M2 steel. In Figure 3d, the FeB layer disappears due to the chemical composition of the boriding mixture. They confirm that the iron boride $(\mathrm{FeB})$ and the iron diboride $\left(\mathrm{Fe}_{2} \mathrm{~B}\right)$ are easily identified on the surface of borided AISI M2. The EDS analysis obtained by SEM at the $\mathrm{FeB} / \mathrm{Fe}_{2} \mathrm{~B}$ interphase is shown in Fig. $4 \mathrm{a}$ 
and the $\mathrm{Fe}_{2} \mathrm{~B}$ layer for the borided AISI M2 steel is shown in Fig. 4b. The powders No. 1, No. 2 and No. 3 , in Table 1, are associated with the formation of thicker, polyphase boride coatings $\left(\mathrm{FeB} / \mathrm{Fe}_{2} \mathrm{~B}\right)$. Likewise, the powder No. 4 in Table 1, allows thicker single $\mathrm{Fe}_{2} \mathrm{~B}$ phase coating to be obtained. The boron rich $\mathrm{FeB}$ phase is not desirable because $\mathrm{FeB}$ is more brittle than the $\mathrm{Fe}_{2} \mathrm{~B}$ phase.

References:

[1] A Graf von Matuschka in "Boronizing", $1^{\text {st }}$ ed. (Carl Hanser Verlag, Munich) p. 12.

[2] JR Davis in "Surface Hardening of Steels: Understanding the Basics", 1 st ed. (ASM, Ohio) p. 213.

[3] KH Habig. Mater. Eng. 2 (1980), p. 83.

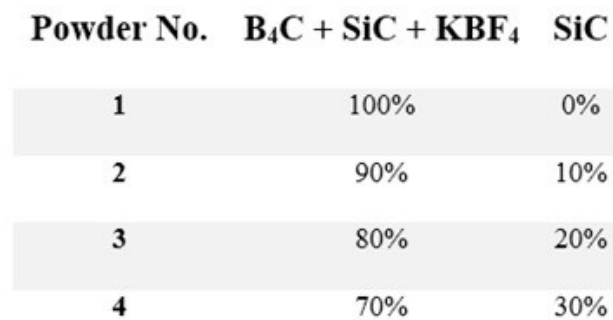

Table 1. Composition of power mixture of boriding processes.

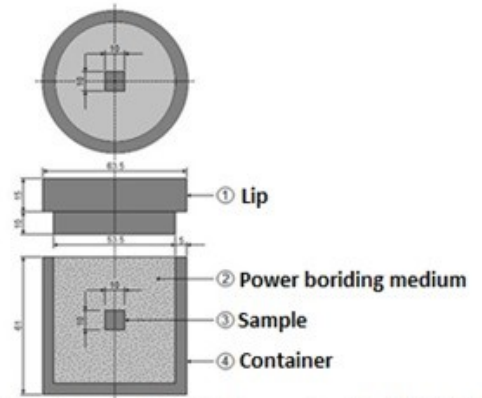

Figure 1. Schematic view of stainless steel AISI 304.
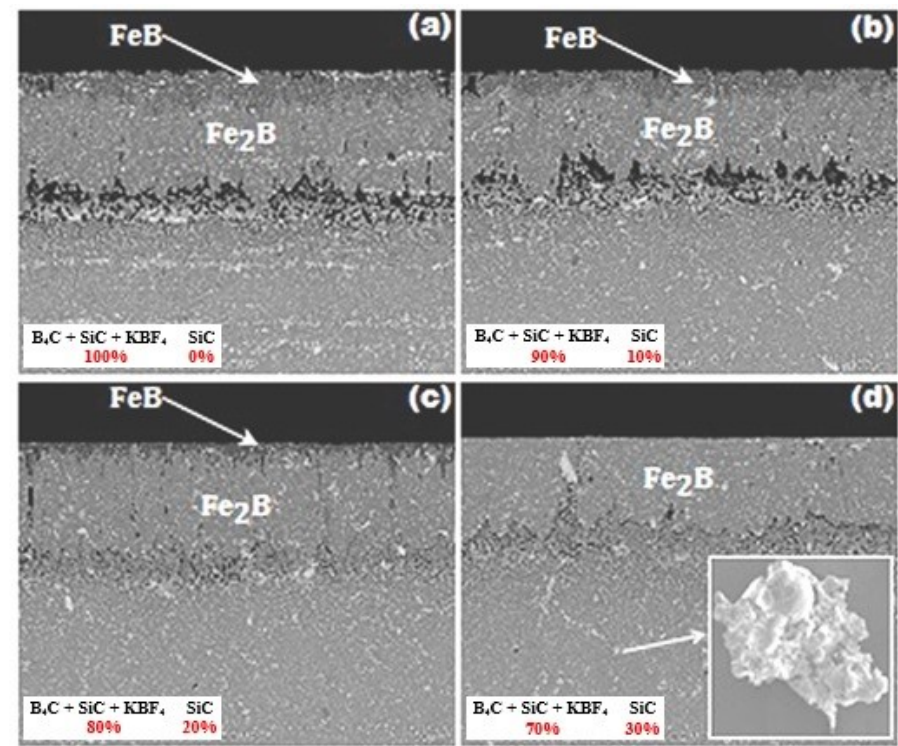

Figure 2. Image (SEM) cross-sectional of borided AISI

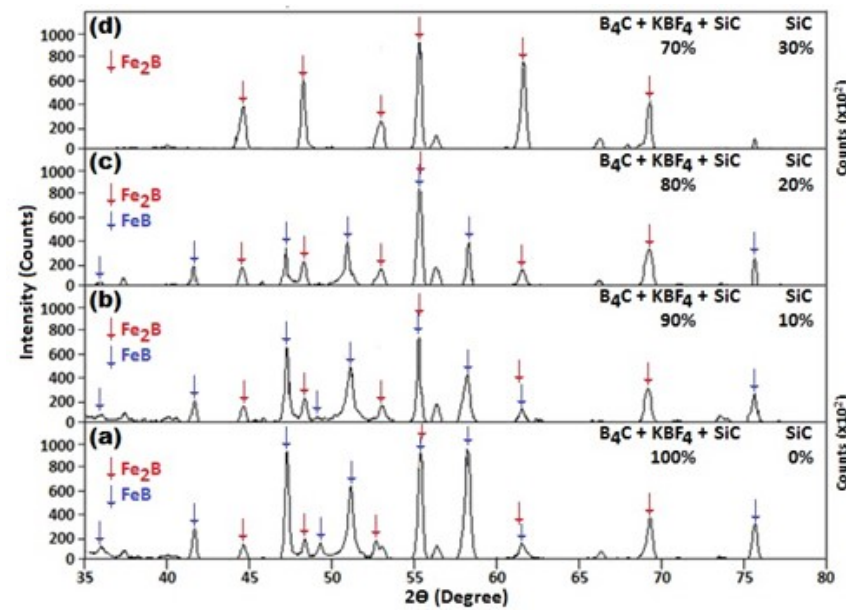

Fig. 3

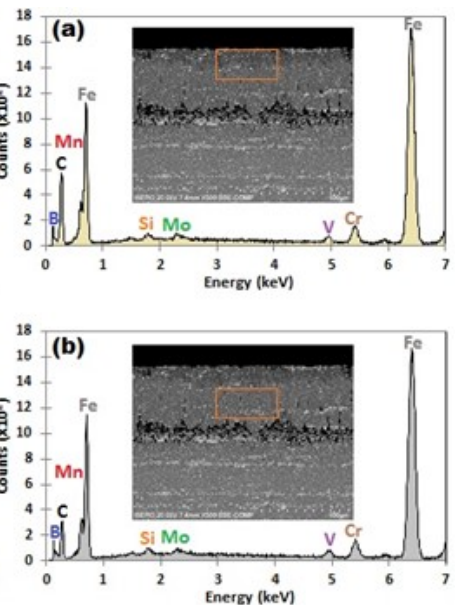

Fig. 4

Figure 3. XRD diffraction patterns of: (a) powder No. 1, (b) powder No. 2, (c) powder No. 3, and (d) powder No. 4 at $1273 \mathrm{~K}$ for 8 hours and EDS (Figure 4) spectrum of borided sample at $\mathrm{FeB} / \mathrm{Fe}_{2} \mathrm{~B}$ interface (a) and (b) $\mathrm{Fe}_{2} \mathrm{~B}$ layer at $1273 \mathrm{~K}$ for 8 hours of treatment and using the powder No. 1. 